\title{
Legacies of Slavery and Popular Traditions of Freedom in Southern Senegal (186o-196o)
}

\author{
Alice Bellagamba* \\ University of Milan-Bicocca \\ alice.bellagamba@unimib.it
}

\begin{abstract}
This study examines the historical linkages that developed between experiences of enslavement, the legacies of slavery, and ideas of freedom before and after abolition in the early twentieth century in an area of southern Senegal known today as the Kolda region. In the Fulfulde language, spoken by the majority of the population, there are several terms and expressions to talk about freedom. The first is ndimaaku, which people tend to equate with nobility and dignity. This is the freedom of the olden days of slavery, when the capacities and qualities of the male or female freeborn stood in stark contrast to those of the slave, and being free meant not having been a slave in the first place. The second term is hebtaare, i.e., freedom in the sense of tranquility, economic well-being, and a general ease in life and social relations. The expression jeyaal-hoore mun conveys a sense of independence, self-mastery and autonomy, while hebtugol hoore mun literally means to retrieve one's head, the center of individual thought and capacity for independent action. Politically, hebtugol hoore mun stands for the end of colonial rule and the achievement of national independence. Socially, it refers to
\end{abstract}

* Research for this article was carried out between 2014 and 2016 thanks to funding from the European Research Council in the framework of the ERC project 31373-Shadows of Slavery in West Africa and Beyond: A Historical Anthropology. I thank Elhadji Chiekou Baldé, for his assistance and friendship throughout the lengthy work of collecting and transcribing oral history, Hamadou Kandé for the invaluable help during fieldwork, Fente Boiro for the linguistic assistance, Mountaga Diao for the historical conversations, and Fatou Diao for the company and friendship. Hawa Kandé and Bouraima Diao welcomed me in their home, while a legion of other people spent their time answering my endless questions over the history and social structure of the region. Riccardo Ciavolella, Martin A. Klein, Sheriff Kora, Paul Lovejoy and Benedetta Rossi were careful readers of earlier versions of this article. To all of them my gratitude and affection. 
the emancipation of subordinated groups, like the youth and women, and it describes slaves who freed themselves from their masters. Drawing from archival sources and oral history, this essay attempts to reconstruct the discursive reconfigurations of local ideas of freedom within the context of the political and social changes that affected the Kolda region in the late nineteenth century, the early colonial period, and the years before decolonization. Each historical period had its own actors, dynamics and complexities in which slavery and then legacies of slavery played a role in the definition of freedom and the entitlement of people to its benefits. As demonstrated here, however, liberation paved the way for other forms of subjugation.

\section{Keywords}

freedom - slavery - emancipation - Fulbe - southern Senegal

\section{Introduction}

What is meant by "freedom" is one of the least documented aspects of past and present African social life. There are of course exceptions, such as the seminal study of Paul Riesman on the construction of self and society amongst the Peul Jelgobe of Upper Volta (today Burkina Faso), or Harri Englund's ethnography of human rights activism in Malawi. ${ }^{1}$ Otherwise, Africa looms largely as the continent of unfreedom: the slave trade, colonial subjugation, Cold War dictatorships, the apartheid regime, civil wars, environmental disasters, and contemporary façade democracies all compound this image. Both anthropologists and historians have stressed African resilience to historical adversities, and theorized agency "not in terms of dependence and independence, but interdependence and intersubjectivity."2 Many have indeed described interrelatedness as a historically consolidated strategy of survival — a way to distribute

1 Paul Riesman, Freedom in Fulani Social Life: An Introspective Ethnography (Chicago: University of Chicago Press, 1977); Harri Englund, Prisoners of Freedom: Human Rights and the African Poor (Berkeley: University of California Press, 2006).

2 Francis Nyamnjoh, “'A Child is One Person's only in the Womb:' Domestication, Agency and Subjectivity in the Cameroonian Grassfields," in Richard Werbner, ed., Postcolonial Subjectivities in Africa (London: Zed Books, 2002), 112; J. Ferguson, "Declarations of Dependence: Labour, Personhood, and Welfare in Southern Africa," Journal of the Royal Anthropological Institute 19, no. 2 (2013): 223-242; Benedetta Rossi, "Dependence, Unfreedom and Slavery in Africa: Towards an Integrated Analysis," Africa 86, no. 03 (2016): 571-590. 
individual success to social networks and communities that in turn provide refuge in times of need. Freedom is the unwelcome topic of these discussions, one which only new scholarship on African nationalist movements and decolonization has begun to assess as "a word-in-motion" across historical contexts and circumstances. ${ }^{3}$

Most of the contribution of African slavery studies to the historicizing of freedom has come from studies that prioritize the meanings of slavery, the variety of slaves' conditions and the post-abolition consequences of African slavery pasts. ${ }^{4}$ This study attempts to place the analysis of freedom in the foreground by focusing on the part of southern Senegal that was called the Upper Casamance during French rule and is today known as the Kolda region. The objective is to explore the historical linkages between enslavement, the legacies of slavery and changing ideas of liberty in three historical periods: the late nineteenth century, the early colonial period, and the years of decolonization.

Historians have produced a wealth of knowledge on the pre-colonial Kolda region, but the twentieth century remains partly unexplored. ${ }^{5}$ Until the sec-

3 Emma Hunter, Political Thought and the Public Sphere in Tanzania (Cambridge: Cambridge University Press, 2015), 136.

4 Igor Kopytoff and Suzanne Miers, "African Slavery as an Institution of Marginality," in Suzanne Miers and Igor Kopytoff, eds., Slavery in Africa: Historical and Anthropological Perspectives (Madison: University of Wisconsin Press, 1977), 17; Frederick Cooper, From Slaves to Squatters: Plantation Labour and Agriculture in Zanzibar and Coastal Kenya, 1890-1920 (New Haven: Yale University Press, 1982); Paul E. Lovejoy, "Murgu:The Wages of Slavery in the Sokoto Caliphate," Slavery and Abolition 14, no. 1 (1993): 168-185; Paul E. Lovejoy, Transformations in Slavery: A History of Slavery in Africa, 2nd edition (Cambridge: Cambridge University Press, 200o), 245. See also J. Glassmann, “The Bondsman's New Clothes: The Contradictory Consciousness of Slave Resistance on the Swahili Coast," Journal of African History, 32, no. 2 (1991): 281; Frederick Cooper, Thomas Holt and Rebecca Scott, Beyond Slavery: Explorations of Race, Labor, and Citizenship in Postemancipation Societies (Chapel Hill: University of North Carolina Press, 2000): 9-11; Sean Stilwell, Slavery and Slaving in African History (New York: Cambridge University Press, 2014).

5 J. Girard, "Note sur l'histoire traditionnelle de la Haute Casamance," Bulletin de l'Institut Fondamental d'Afrique Noire, Série B: Sciences humaines 28, no. 1 (1966): 540-554; C. Quinn, "A Nineteenth Century Fulbe State," The Journal of African History 12, no. 3 (1971): 427-440; Christian Rôche, Histoire de la Casamance: conquête et résistance, 1850-1920 (Paris: Karthala, 1985); Joyce Bowman, Ominous Transition: Commerce and Colonial Expansion in the Senegambia and Guinea, 1857-1919 (Aldershot: Avebury, 1997); René Pélissier, Naissance de la Guinée. Portugais et Africains en Sénégambie (1841-1936) (Orgeval: Pélissier, 1989); Sylvie Fanchette, Au pays des Peuls de Haute-Casamance: L'intégration territoriale en question (Paris: Karthala, 2011); Abderrahmane N'gaïdé, "Identités ethniques et territorialisation en Casamance," in Michel Ben Arrous and Lazare Ki-Zerbo, eds., Etudes Africaines de Géographie par le Bas (Dakar: 
ond half of the nineteenth century, Mandinka was the vehicular language for the entire area south of the Gambia River. Because of political changes and population movement, Fulfulde then became dominant. ${ }^{6}$ The shift was caused by the political collapse of Kaabu, ${ }^{7}$ the loose confederacy of small Mandinka states that since the fifteenth century controlled the lands between the middle and upper reaches of the Gambia River and the northeastern part of the BissauGuinean region, where in the 185 os its capital Kansala was located. ${ }^{8}$ None of the travelers who crossed southern Senegambia in this period ever visited it, although they paid respect to the Almamy of Bundu and to that of the Fouta Djallon. ${ }^{9}$ The two Imamates controlled the flow of hinterland trade towards the coastal and riverine European settlements, ${ }^{10}$ and viewed Kaabu as their frontier

Codesria, 2009), 39-77. Mouhamadou Moustapha Sow, Mutations politiques et sociales au Fuladu: la chefferie locale à l'épreuve du pouvoir colonial, 1867-1958 (PhD dissertation, University of Dakar, 2011).

6 Philip J. Havik, Silences and Soundbites: The Gendered Dynamics of Trade and Brokerage in the Precolonial Guinea Bissau Region (Münster: LIT Verlag, 2004), 123.

7 M. Mané, "Contribution à l'histoire du Kaabu, des origines au xıxe siècle," Bulletin de l'Institut Fondamental d'Afrique Noire, Série B: Sciences humaines 40, no. 1 (1978): 87-159; George E. Brooks, Landlords and Strangers: Ecology, Society, and Trade in Western Africa, 1000-1630 (Boulder: Westview Press, 1993); M. Benoît, "Espaces francs et espaces étatisés en Afrique occidentale," Cahiers des Sciences Humaines, 24, no. 4 (1988): 503-519; Toby Green, The Rise of the Trans-Atlantic Slave Trade in Western Africa, 1300-1589 (Cambridge: Cambridge University Press, 2011); Carlo Lopes, Les Kaabunke: structures politiques et mutations (PhD dissertation, University of Paris, 1988); Djibril Tamsir Niane, Histoire des Mandingues de l'Ouest: le royaume du Gabou (Paris: Karthala, 1989); Havik, Silences and Soundbites.

8 Boubacar Barry, La Sénégambie du Xve au XIxe siècle: traite négrière, Islam et conquête coloniale (Paris: L'Harmattan, 1988); Nathan Riley Carpenter, Sovereignty Along a West African Frontier: The Creation of the Guinea-Senegal Border, 1850-1920 (PhD dissertation, University of California, Davis, 2012), 41-42; Joshua Forrest, Lineages of State Fragility (Athens: Ohio University Press, 2003), 67.

9 Philip D. Curtin, Economic Change in Precolonial Africa: Senegambia in the Era of the Slave Trade (Madison: University of Wisconsin Press, 1975); Barry, La Sénégambie, xx; see also A.F. Clark, "The Fulbe of Bundu (Senegambia): From Theocracy to Secularization," The International Journal of African Historical Studies 29, no. 1 (1996): 1-23; Michael A. Gomez, Pragmatism in the Age of the Jihaad: The Precolonial State of Bundu (Cambridge: Cambridge University Press, 2002).

10 "Correspondence relating to the recent expedition to the Upper Gambia under Administrator V.S. Gouldsbury, Presented to the House of Parliament by Command of Her Majesty, August 1881," in Irish University Press Series of British Parliamentary Papers: Gambia (Shannon: Irish University Press, 1971), 407. 
of expansion. This external pressure added to Kaabu internal difficulties. Historians have explained the crisis of the confederacy within the context of the decline of the Atlantic slave trade and the parallel development of commercial groundnut cultivation in the regions south of the Gambia River. The first deprived the Kaabu Mandinka elite of their major source of revenue, while the second placed wealth to buy European weapons into the hands of commoners. ${ }^{11}$ Another important factor was Islamic reformism. While one part of the population followed traditional cults, the other was sensible to the proselytism of Islamic preachers who urged the separation of Muslims from unbelievers' settlements after centuries of peaceful cohabitation. These were the first moves towards the Islamic wars that tore Senegambia apart in the second half of the century. ${ }^{12}$ The most dangerous internal enemies of the Kaabu confederacy were the Muslim Mandinka, who supported Fouta Djallon, ${ }^{13}$ and the Fulbe communities that dwelt in Kaabu lands. ${ }^{14}$ In the eyes of Bundu and Fouta Jallon, all of these were natural allies. ${ }^{15}$

Emmanuel Betrand Bocandè, a French resident in the Casamance between 1849 and 1857, noted that the influence of Mandinka chiefs depended on the number of foulacounda - Fulbe villages - under their control, as these villages were a source of milk, meat and young men who fought alongside Mandinka youths. ${ }^{16}$ Bocandé also described the heavy presence of Fouta Djallon people in the western areas of Kaabu as much as sources of the same period reported regular raids of the Imamate along the middle and upper reaches of the Gambia River. ${ }^{17}$ Mud walls and stockades encircled all large Mandinka settlements, and caravans employed their own militia to protect men and goods. ${ }^{18}$

11 Martin A. Klein, "Social and Economic Factors in the Muslim Revolution in Senegambia," The Journal of African History 13, no. 3 (1972): 419-441.

12 David Robison, The Holy War of Umar Tal: The Western Sudan in the Mid-19th Century (London: Clarendon Press, 1985); Barry, La Sénégambie; John Ralph Willis, In the Path of Allah: The Passion of Al-Hajj 'Umar: An Essay into the Nature of Charisma in Islam (New York: Franck Cass, 1989).

13 Niane, Histoire, 158-159.

14 E. Bertrand-Bocandé, "Notes sur la Guinée portugaise ou Sénégambie méridionale," Bulletin de la Société de Géographie 12, no. 2 (Jul./Aug. 1849): 58-59.

15 Barry, La Sénégambie, 239-240.

16 Bertrand-Bocandé, "Notes sur la Guinée portugaise," 58.

17 See for instance William Fox, A Brief History of the Wesleyan Missions on the Western Coast of Africa: Illustred with a Map, and Six Engravings (London: Aylott and Jones, 1951); Louis Hyacinte Hecquard, Voyage sur la côte et dans l'intérieur de l'Afrique occidentale (Paris: Bénard et compagnie, 1855). See also Rôche, Histoire de la Casamance, 127.

Niane, Histoire, $15^{8-159}$. 
Large-scale hostilities started around 1850, when Labé, the northern province of Fouta Djallon, mobilized an army of nearly six thousand men to defeat Berekelon, one of the strongholds of Mandinka rule. ${ }^{19}$ Then, the joined forces of Fouta Djallon, Bundu and their local allies destroyed Kansala in $1867 \cdot{ }^{20}$ While the British, French and Portuguese prepared colonial occupation, the peripheral leaders of Kaabu asserted their autonomy in the wake of collapsing Mandinka hegemony. ${ }^{21}$

One of these leaders was Alpha Molo Balde, also known as Molo Eggue, a convert to Islam and ally of Bundu and Fouta Jallon, who in the early $1870 \mathrm{os}$ began to negotiate military and economic collaboration with the British and the French. ${ }^{22}$ The former were stationed at McCarthy Island, a commercial outpost established in 1823 that was located about 250 kilometers from the coast in the middle of the Gambia River. The French were at Sedhiou, the fort they constructed in 1838 on the north bank of the Casamance River. In 1875, Molo's army swept across the southern bank of the Gambia River from east to west, and then moved south into Guinea Bissau. ${ }^{23}$ Under his military leadership, the western part of the Kaabu Confederacy became Fuladu, which in Mandinka means "the land of the Fula." All sources insist on the fact that Molo was of slave origins. When he died in 1881, his son Musa Molo Balde established himself as Fuladu's legitimate leader, thanks to French military support. This collaboration, marked by treaties signed in 1883 and 1896, ended in 1903, when Musa left his capital of Hamdallay, located north of the contemporary city of Kolda, to seek refuge in the part of Fuladu that he had ceded to British Gambia in 1901. ${ }^{24}$ Fuladu ended up splitting into the British districts of Fuladu West and Fuladu East, the French Upper Casamance, and the Portuguese region of Gabu.

The first section of this study reconstructs the vision of freedom that Molo and Musa subscribed to by drawing on ethnography - specifically early accounts on Fuladu and Fulbe social organization that were written by the British and French on the basis of local information ${ }^{25}$ - as well as oral history,

\footnotetext{
19 Barry, La Sénégambie, 240-241.

20 Barry, La Sénégambie, 241; Rôche, Histoire de la Casamance, 127.

21 Carpenter, Sovereignty, 33.

22 Archives Nationales du Sénégal (ANS), Dakar, 1G-193, Notice historique sur le poste de Sédhiou (de 1838 à 1883) par M. Adam, 1891, 14-15 and 21-26; Gambian National Archives (GNA), Banjul, CSO 1/141, Despatches to Sierra Leone, no. 34 (30 Mar. 1875), n. 12 (19 Jul. 1875).

23 Barry, La Sénégambie, 240-241; John Gray, A History of the Gambia (Cambridge: Cambridge University Press, 1940), 451.

24 Rôche, Histoire de la Casamance, 237-263.

25 ANS, 1G 75, Mission Liotard 1887-1888; ANS, 1G-193, Notice historique sur le poste de Sédhiou
} 
collected both in The Gambia and Senegal since the $1960{ }^{26}{ }^{26}$ It also delves into the Fulfulde vocabulary of freedom and slavery, as there is no way to understand the concreteness of both without some historical semantic analysis. ${ }^{27}$ The late nineteenth century, which historians describe as a time of massive enslavement for the whole of West Africa, ${ }^{28}$ offered opportunities for social emancipation to part of the servile population of Fuladu. ${ }^{29}$ The second section explains how this process was halted in the colonial period, despite the

(de 1838 à 1883) par M. Adam, 1891; ANS, 13 G 373, 1895-1888, Casamance, Mission de Captaine Baurés, 2 Aug. 1894; ANs 1 G 343, Monographie de la Casamance, 1917; The National Archives (TNA), Kew Gardens, UK, Co 87/74, 24 Oct. 1862, Governor D'Arcy, Civil War between the Natives around MacCarthy Island; TNA co 87/85, 20 Jul. 1866, Governor D'Arcy, Upper River Gambia; TNA co 87/129, 26 Oct. 1886, Firdu Country; TNA co 879/29/4 Confidential Prints (Gambia 1889), Administrator Carter, 27 Mar. 1889, Tour in the Upper River; TNA co 879/32/2, Territories on the River Gambia: Further Correspondence; TNA co 87/179, 18 May 1908, Enclosure: Short History of Moussah Molloh, compiled by Captain Stainley. Evidence on the history of Fuladu was collected by French and British colonial officials in the 1930s and again the 1950s. For the French: ANS, $2 \mathrm{G} 32$ 102, Sénégal, Cercle de Kolda, Rapport Politique Annuel 1931. I accessed British materials, which include statements of people close to Musa Molo and of his son Cherno Kady (Copy of a note by Cherno Kaddy Bande, Seyfu of Fuladu West, 1938ca), in the private archive of Bakary Sidibeh, Banjul, The Gambia.

26 Much of this oral history is kept at the archives of the Research and Documentation Division of the National Centre for Arts and Culture of Banjul (The Gambia). My personal collection consists of ethnographic materials and historical narratives that I collected between 1992 and 2017 on both the Gambian and the Senegalese side of the border on issues such as the careers of Molo and Musa, colonial chieftaincy, forced labour, political parties and independence, slavery, the slave trade and the legacies of slavery, mobility and migration. Printed sources include Sekene M. Cissoko and Sambou Kaoussou, Recueil de traditions orales des Mandingues de Casamance et de Gambie (Dakar: IFAN, 1969); Gordon Innes, Kaabu and Fuladu: Historical Narratives of the Gambian Mandinka (London: School of Oriental and African Studies, 1976); Matt Schaffer, ed., Djinns, Stars, and Warriors: Mandinka Legends from Pakao, Senegal (Leiden: Brill, 2003).

27 Bronislav Malinowski, Freedom and Civilization (1947; New York: Routledge, 2015), 43-52; Englund, Prisoners, 47-69.

28 Lovejoy, Transformations, 136-137; Martin A. Klein, "The Slave Trade in the Western Sudan during the Nineteenth Century," Slavery and Abolition 13, no. 1 (1992): 39-6o; Martin A. Klein, Slavery and Colonial Rule in French West Africa (Cambridge: Cambridge University Press, 1998), 37-42.

29 Alice Bellagamba, Ethnographie, histoire et colonialisme en Gambie (Paris: L'Harmattan, 2002); Abderrahmane N'gaïdé, L'esclave, le colon et le marabout. Le royaume peul du Fuladu de de 1867 à 1936 (Paris: L'Harmattan, 2012). 
1905 abolition of slavery in French West Africa. ${ }^{30}$ Under the Republican motto of liberty, equality and fraternity, the French administration became the unwitting supporter of social and political restoration of the former master class over freed slaves and slave descendants. The third section explores the battles for citizenship of the 1950s. The political leaders of this period pressed for liberation from colonial rule in terms of emancipation from slavery. As Mary Nyquist explains, such metaphorical usages have a long history worldwide, "none of which arises from concern for those who are actually enslaved." ${ }^{31}$ In contexts where the legacies of slavery are perceptible in daily life, like the Kolda region, these discourses often acquire a literal turn, and battles against external and internal subjugation tend to overlap.

As made clear by a census carried out for the first development plan of Senegal, ${ }^{32}$ freed slaves and slave descendants constituted more than half of the population of the present Kolda region in the late 1950s. This situation opens a window on the emancipation struggles that developed locally in relation to anti-colonial mobilization and debates over citizenship. Leopold Sédar Senghor and his close political associate Mamadou Dia are widely recognized as the undisputed protagonists of this period..$^{33}$ Many of the old militants I met while conducting fieldwork, however, thought otherwise. Their hero was Yoro

F. Renault, “L' Abolition de l' esclavage au Sénégal: l' attitude de l' administration française (1848-1905)," Revue française d' histoire d'outre-mer 58, no. 210 (1971): 5-81; Richard Roberts, "The End of Slavery in the French Soudan, 1905-1914," in Suzanne Miers and Richard Roberts, eds., The End of Slavery in Africa (Madison: University of Wisconsin Press), 282307; M. Badji, "L'abolition de l' esclavage au Sénégal: entre plasticité du droit colonial et respect de l'état de droit," Droit Et Culture. Revue internationale interdisciplinaire [En Ligne] $5^{2}$ (2006): 239-274 (accessed at http://droitcultures.revues.org/729 on 20 Oct. 2016).

31 Mary Nyquist, Arbitrary Rule: Slavery, Tyranny, and the Power of Life and Death (Chicago: University of Chicago Press, 2013), 2-3.

32 Jean-Louis Boutillier, Les villages du Fouladou en 1959, Recensement socio-démographique des cantons, Document produits dans le cadre des études préparatoires au Premier Plan de Développement du Sénégal, (accessed at http://www.histoire-ucad.org/archives/index .php/ressources/accueil-bibliothequevirtuelle.html, 6 Jul. 2015); for a comparison with Portuguese Guinea, see Avelino Teixeira Da Mota, Guine Portuguesa, vol. 2 (Lisbon: Agencia Geral do Ultramar, 1954), 275.

33 Gerti Hesseling, Histoire politique du Sénégal: institutions, droit et société (Paris: Karthala 1985); Roland Colin, Sénégal notre pirogue: au soleil de la liberté: journal de bord 1955-1980 (Paris: Editions Présence Africaine, 2007); Gary Wilder, Freedom Time: Negritude, Decolonization, and the Future of the World (Durham: Duke University Press, 2014); Frederick Cooper, Citizenship between Empire and Nation: Remaking France and French Africa, 19451960 (Princeton: Princeton University Press, 2014). On Yoro Kande see Christian Rôche, Le Sénégal à la conquête de son indépendance: 1939-196o (Paris: Karthala, 2001), Assane Seck, 
Kande, a young schoolteacher who built upon the historical tradition of Molo and Musa to raise the civil awareness of-and a sense of historical agency among-freed slaves and slave descendants. One of Kolda's public secrets is that Yoro himself was of slave ancestry: thanks to his initiative, decolonization again opened the local debate over the meanings of freedom and slavery. The time of Molo and Musa, the early colonial period, and the period of Yoro's involvement in the political mobilization that led to the independence of Senegal in 1960, shared similarities but were also quite different: each period had its own actors, dynamics and complexities in which slavery and subsequently its legacies played a role in the discursive reconfigurations of freedom. I hope that this anthropological history paves the ways to appreciating the variety of ways in which ordinary people moved along the uneven paths of emancipation and experienced the unfreedom that was consequential to the conquest of freedom.

\section{Emancipation through War in the Second Part of the Nineteenth Century}

Combining early colonial reports with oral history, historians have long explained the emergence of Fuladu and Molo's political success in terms of the ethnic cleavage between the Kaabu Mandinka and the Fulbe. ${ }^{34}$ The former ruled the land; the latter had economic power. Outraged by Mandinka pillaging, the Fulbe capitalized on the support of Fouta Djallon and Bundu to liberate themselves.

Boubacar Barry and Martin Klein have integrated this vision by underlining Fulbe internal hierarchies. ${ }^{35}$ Although Bertrande-Bocandé described foulacounda as homogenous communities under patriarchal authority, ${ }^{36}$ hierarchy did matter, in particular that between the freeborn and the slave. ${ }^{37}$ The only

Sénégal, émergence d'une démocratie moderne, 1945-2005: un itinéraire politique (Paris: Karthala, 2005).

34 Mané, "Contribution à l' histoire du Kaabu”; Quinn, "A Nineteenth Century"; Al Haji Bakary Sidibé, A Brief history of Kaabu and Fuladu (1300-1930): A Narrative Based on Some Oral Traditions of the Senegambia (West Africa) (Turin: L'Harmattan Italia, 2004).

35 Barry, La Sénégambie, 171; Klein, Slavery, 146-147.

36 Bertrand-Bocandé, "Notes sur la Guinée," 58.

37 For instance Gaspard Théodore Comte de Mollien, Voyage dans l'intérieur de l'Afrique: aux sources du Sénégal et de la Gambie, fait en 1818, par ordre du gouvernement français, vol. 2 (Paris: Imprimerie de Mme Ve Courcier, 1820); Hecquard, Voyage sur la côte. The contri- 
Mandinka term for freedom is foroyaa. In Molo's time, this kind of freedom was the hereditary status of men and women (sing. foro; plur. forolu) who were part of the ruling elite, trading or Muslim religious families, and professional endogamous groups of bards, leatherworkers and blacksmiths. The opposite of foroyaa was jongyaa: slavery. The slave was called jongo (plur. jongolu); the same term tellingly served to indicate "mixed" or "impure" materials such as the alloys of gold or silver with other metals. Referring to the Fulbe that dwelled in Kaabu lands, the Mandinka spoke of fula foro-free or "pure" Fulbe-and fula jongo — slave or "impure" Fulbe, a distinction also reported by early French and Portuguese sources on Fuladu, as well as by oral history. ${ }^{38}$

Fulfulde vocabulary on freedom is richer. There are at least three interrelated ways to speak about freedom. ${ }^{39}$ The first is ndimaaku, a term that in this period had the same meaning as foroyaa: it meant freedom in the aristocratic sense of hailing from prestigious families. It also identified freemen (plur. rimbe; sing. male dimo; sing. female: fulde6o) as not being slaves. ${ }^{40}$ The latter were called macchube (sing. maccudo) or jiyaabe (sing. jiyaado), together with a variety of other terms that reminded them of their subjection to rimbe. ${ }^{41}$

bution of travelers and colonial officials to the understanding of Fulbe societies is well summarized by P. Brasseur and G. Brasseur, "Le peul imaginaire," Revue française d' Histoire d'Outre-mer 65, no. 241 (1978): 535-542. See also Tenant Stanley, Notes on the Physical Distribution of the Country and the Political Organization of the Fullahs of the Gambia, their Customs and Laws, etc. (1907), originally classified as GNA Cso 76, Dr. Gamble's files and now GNA NGR/1 31.

38 Research and Documentation Division, National Council for Arts and Culture, Banjul (The Gambia), Recording 475 A and B, 9 May 1978, Al Haji Kawsu Sillah, Fuladu History.

39 I follow here the Fulbe orthography of Oumar Bah, Dictionnaire Pular-Francais. Accessed at http://pular.webonary.org/files/Dictionnaire-Pular-Francais.pdf on 1 Sept. 2016.

40 Maxwell R. MacBrair, Grammar of the Fulah Language (London: Rison and Sons, 1854), 46; Louis Léon César Faidherbe, Essai sur la langue Poul: grammaire et vocabulaire (Paris: Maisonneuve, 1875), 111.

41 For women the term is kordo (plur. horbe), while kaado (pl: haabe) can be used for both men and women, as much as the two terms that describe the condition of the slave: maccungaaku and njiyaagu. The specific meanings of these words change according to historical periods and Fulfulde communities. In the Kolda region, jiyaado is more used than maccudo, and N'gaïdé (L'esclave, 92, fn. 132) remarks the change of significance that the term acquired since Molo Eggue's times. Today, maccudo stands for the captive or the chattel slave, while jiyaado is often translated as serf or slave descendant, like in Guinea Conakry. Jiyaado, however, can equally mean, and probably meant in the past, the newly acquired slave. See M. Bazemo, "Une approche de la captivité par le vocabulaire chez 
The second word that conveyed a sense of freedom (but also autonomy, selfsufficiency and independence) was hebtaare. Mi hebtima means "I am fine"indicating no worry, hunger, illness, or conflict - while mi hebtaaki is used for "I am restrained," or "I am pressed." Herders of Molo's time sought hebtaare when they selected a place to stay with their cattle: a site that was far from farmers (so as to avoid conflict over spoiled crops), close to water and grassy areas, in harmony with the spiritual entities of the territory, and safe from cattle thieves and slave raiders. In this perspective hebtaare implied a lack of restraints but also a positive conception of freedom in the sense that John Christman proposes: the person had the economic and social capabilities to handle one's life at its best. ${ }^{42}$ The expression jeyaal-hoore mun, literally "the property of one's head," describes the sense of self-autonomy that the individual achieves with full adulthood: the ability to formulate purposes and turn them into action in the awareness of being part of a larger social environment that demands respect for its rules and feelings. This kind of self-mastery is one of the pillars of ndimaaku freedom. The dimo of Molo's times took care of other people's needs, and the hebtaare of his life was in principle the hebtaare of all the people that lived under his protection. The fuldebbo ${ }^{43}$ acted kindly towards all people,

les Peuls du Djelgoji (Djibo) et du Liptaako (Dori) à l'époque précoloniale et coloniale," Dialogues d'histoire ancienne 16, no.1 (1990):403-423. For both maccudo and jiyaado, there are popular etymologies. Following the interpretation given in 196os by Yaya Wane, and embraced by several other scholars, the first should mean "somebody who is lost". See Yaya Wane, Les Toucouleurs du Fouta Toro (Dakar: Institut Fondamentale d' Afrique Noire, 1969), 67 . From the root yey (to own), jiyaado could mean "he, who is owned"; from the same root comes the term jeyal: property. The second possibility is yiyeede (to be seen): jiyaado, in that sense, would be "somebody who is seen." For the first interpretation see Botte, "Stigmates," 109, and Cristiane Seydou and David W. Arnott, Dictionnaire pluridialectal des racines verbales du peul: peul, français, anglais (Paris: Karthala, 1998), 142-143; for the second N'gaïdé, L'esclave, 92, fn. 132. Fulfulde has a special word to identify freed slaves; they are the ndiimaabe or riimaabe (sing. ndiimaajo), a category of people apart from the rimbe; this terms, however, is not used in the Kolda region where there are only the dimo and the jiyaado.

John Christman, "Saving Positive Freedom," Political Theory 33, no. 1 (2005): 79-88; Interviews with Fente Boiro, locality of Kounkané, Department of Velingara, Kolda Region, 2 Jan. 2016; Manga Sabally, locality of Kanjaye, Department of Velingara, Kolda Region, 8 Jan. 2016; Doi Sabally, locality of Sare Colly Salle, Department of Velingara, Kolda Region, 9 Jan. 2016; Dembayel Baldé, locality of Saré Bounda, Department of Velingara, Kolda Region, 15 Jan. 2016.

43 Literally "the Fulbe woman." This is an epithet that even today many women of slave origins do refuse to accept, in the conviction that it is not for them, as much as men of the same condition do not like to be called "pullo," which is an equivalent of dimo. 
confronted stoically the adversities of life, helped kin and kindred, and ensured that the new generations learned the values of ndimakuu.

Macchube in principle never achieved jeyaal-hoore mun. Throughout the West African "archipelago" of Fulfulde-speaking communities, the symbol of their condition was boggol- the rope. ${ }^{44}$ This is why oral history, when narrating about Molo, uses the expression: "Molo is the one who cut the rope of slavery." 45 In this context, 6oggol meant the overall subjection of the Fulbe to the Mandinka as much as rimbe's control over their jiyaabe. The version of

44 Literature on Fulbe slavery and its legacies is abundant: Gilbert Pierre Vieillard, Notes sur les coutumes des Peuls au Fouta Djallon (Paris: Larose, 1939), Louis Tauxier, Moeurs et histoire des Peuls (Paris: Payot, 1937); C. Rivière, "Dynamique de la stratification sociale chez les Peuls de Guinée," Anthropos 69, 3/4 (1974): 361-40o; Mamadou Saliou Balde, "L'esclavage et la guerre sainte au Fouta-Jalon," in Claude Meillassoux, ed., L'esclavage en Afrique précoloniale (Paris: Maspero 1975): 183-220; Marguerite Dupire, L'Organisation sociale des Peuls (Paris: Plon 1970); R. Botte., J. Schmitz "Paradoxes identitaires," Cahiers d'Études Africaines 34, no. 133 (Jan. 1994): 7-22; R. Botte, "Stigmates sociaux et discriminations religieuses: l' ancienne Classe Servile Au Fuuta Jaloo," Cahiers d'Études Africaines 34, no. 133 (Jan. 1994): 109-136; C. VerEecke, "The Slave Experience in Adamawa: Past and Present Perspectives from Yola (Nigeria)," Cahiers d'Études Africaines 34, no. 133 (Jan. 1994): 23-53; A.F. Clark, "'The Ties that Bind': Servility and Dependency among the Fulbe of Bundu (Senegambia), c. 1930s to 1980s," Slavery and Abolition 19, no. 2 (1998): 91-108; Cècile Pouget, Evolution des populations serviles dans les sociétés peules d'Afrique de l'Ouest et du Centre (PhD dissertation, University of Paris 10, 2001); I. Saïbou, "Paroles d' esclaves au Nord-Cameroun," Cahiers d'études africaines 45, nos. 179-180 (2005): 853-878; Leservoisier, O. "Les héritages de l'esclavage dans la société haalpulaar de Mauritanie," Journal des africanistes 78, no. 1-2 (2009): 247-267; Ahmadou Sehou, L'esclavage dans les Lamidats de l'Adamaoua (Nord-Cameroun), du debut du XIXe à la fin du du XXe siècle (PhD dissertation, University of Yaounde I, 2010); Lotte Pelckmans, Travelling Hierarchies: Roads In and Out of Slave Status in a Central Malian Fulbe Network (Leiden: African Studies Centre, 2011); E.K. Hahonou, "The Quest for Honor and Citizenship in Post-Slavery Borgu (Benin)," The International Journal of African Historical Studies 48, no. 2 (2015): 325-344. Only Riesman, Freedom, addresses Fulbe vocabulary and ideas of liberty systematically. However, hints on fulbe ideas of personal autonomy and liberties can be found in the literature that explores the notion of puulaku, a concept that expresses the Fulbe social and moral code of behavior in contrast with other ethnic groups. See A. Breedveld, and M. de Bruijn, "L' image des Fulbe: analyse critique de la construction du concept de pulaaku," Cahiers d'études africaines 36, no. 144 (1996): 791-821; see also Catherine VerEecke, Pulaaku: Adamawa Fulbe Identity and Its Transformations (PhD dissertation, University of Pennsylvania, 1988); Tea Virtaten, Performance and Performativity in Pastoral Fulbe Culture (PhD dissertation, University of Helsinki, 2003).

45 National Council for Arts and Culture, Research and Documentation Division, Banjul, The Gambia, Recording 483 A and B, 22/6/1978, Jaly Sanyang Kuyate, Fuladu History. 
Fuladu history narrated by Mohamadou Falai Baldeh, Molo's great-grandchild, strongly emphasizes that the rimbe acquired slaves from the Mandinka and together with them oppressed the jiyaabe: ${ }^{46}$

The wealthy Fulbe were ruling the fula jongo with the help of the Mandinka. It seems that the Mandinka had entrusted all the Fulbe areas to them, and that they were advising the Mandinka. This is how they came to have slaves. The wealthy Fulbe would go to villages, capture children there and bring them to their town, to raise them up. When they grew up, they worked for the Fulbe and were referred to as fula jongo. ${ }^{47}$

Degrees of jiyaabe's subjection varied. There was the tight rope that physically prevented the newly acquired slave from escaping, as well as the loose one that linked slave descendants to their masters' families or turned members of other ethnic groups into Fulbe dependents. ${ }^{48}$ Some jiyaabe lived in their masters' households, especially if they were young and unmarried. Some others dwelled at a short distance. Still others - as was the rule in Fouta Djallonbuilt up separate communities: these were more serfs than slaves in strict terms, though this nuance did not matter in rimbe's eyes. Molo's rope was apparently of the loose type: he grew up close to his master, Samba Eggue Balde. It is controversial whether his father was a chattel slave, as suggested

46 Mohammadou Falai Baldeh began to assemble this version in the 1950s from the recollections of other family members and his personal researches in the former lands of Fuladu. He was repeatedly interviewed by Bakary Sidibeh, then head of the Gambian Cultural Archives, and by Francis Leary and Joyce Bowan in the 1970s, two of the leading scholars in the historical study of Southern Senegambia. In a collection of several tapes, Baldeh reconstructed the whole history of Fuladu. Sidibeh continued his research on this topic in the 1980s. Baldeh's tapes are in the oral archives of the Research and Documentation Division, National Council for Arts and Culture (Banjul, The Gambia). Sidibeh assembled all Baldeh's transcriptions, and turned them into a manuscript history of Fuladu: Mohammadou Falai Baldeh, Fuladu History, unpublished manuscript, Bakary Sidibeh's private archive, Banjul, The Gambia. I am grateful to Sidibeh' for letting me see this text. Part of the information is published in Sidibé, A Brief History. I first met Mohammadou Falai Baldeh in the 1990s: Interview with Mohammadou Falai Baldeh, locality of Yoroberikunda (The Gambia), 27 Oct. 1994, 10 Nov. 1994, 8 Dec. 1994, 28 Dec. 1997. On Molo's origins, see also Quinn, "A Nineteenth Century Fulbe State," 428.

47 Baldeh, Fuladu History.

48 For a case similar to Fuladu, see VerEecke, "The Slave Experience," 30. 
by Samba Eggue's descendants, ${ }^{49}$ or a stranger, as according to Mohamadou Falai Balde's version. ${ }^{50}$ Both could be right, as the categories of maccudo and jiyaado embraced the war captive, the chattel slave, the child of a different ethnic group entrusted to Fulbe herdsmen, and the stranger who was not dimo and sought integration into Fulbe communities without ever being considered Fulbe, despite mastery of the Fulbe language and habits. All the descendants of these people were macchube (or jiyaabe), and their subordinated status spilled over generations. They conquered relative hebtaare, especially if they lived, like Molo, in separate communities, but always under rimbe protection. The dimo donated cattle for the life-cycle ceremonies of his jiyaado, and the offspring and milk of that cattle belonged to the jiyaado, but if kept within the herd of the dimo it could be disposed of by the dimo without discussion. The same could happen to the cattle of the dimo wives and children. The jiyaado reciprocated by cultivating the dimo's fields, and by giving a share of his crop, if he settled alone.

Each social category needed the other: the rimbe could not do without the labor force of the jiyaabe, whilst the jiyaabe relied on rimbe pastoral riches during the hard times of the rainy season. Their relation also had moral implications: "there could not be a dimo — as some elders say today—without a jiyaado by his side." ${ }^{51}$ The generosity of the former related to the dependence of the latter; their respective personalities integrated the other. The crucial point is that the relative hebtaare of some jiyaabe never meant ndimakuu: purity of origins. One had to be born dimo in order to learn and display ndimakuu freedom, and only a dimo was a true Fulbe: dimo and pullo - the term to indicate the Fulbe man - were interchangeable. Did Molo and Musa ever claim this kind of freedom for themselves?

This is a delicate topic because today, if asked about ndimaaku, some jiyaabe change the subject, as they fear the shame (hersa, called seemtende in other parts of the Fulbe archipelago $)^{52}$ which results from entering into a discussion that does not really belong to them..$^{53}$ Being hersa one of the core qualities of ndimaaku, they show in action (but not in words) their sound knowledge of the

\footnotetext{
49 Interview with Saba Ndyaye Balde, Kolda, 4 Feb. 2014.

5o Baldeh, Fuladu History.

$5^{1}$ Interview with Manga Sabally, locality of Kanjaye, Department of Velingara, Kolda Region, 8 Jan. 2016.

52 Riesman, Freedom, 137-140; VerEecke, "The Slave Experience," 30-31.

53 Interviews with Doi Sabally, locality of Sare Colly Salle, Department of Velingara, Kolda Region, 9 Jan. 2016; Interview with Dembayel Baldé, locality of Saré Bounda, Department of Velingara, Kolda Region 19 Feb. 2014 and 15 Mar. 2016.
} 
kinds of restraints that this kind of freedom implies, certainly the self-restraint of not trespassing the thresholds that keep human harmony in place. Oral history provides a clue to this aspect thanks to well-known episodes in which Molo and Musa commented on slavery, enslaved other people, freed their own subjects from slavery and tamed the political ambitions of rimbe. Their intention was to claim ndimaaku through actions rather than words. First, rimbe used their tight social networks to ransom their enslaved relatives. ${ }^{54}$ Molo and Musa freed their enslaved subjects, ${ }^{55}$ and they enslaved rimbe to break down their sense of social superiority. ${ }^{56}$ Second, a carefully orchestrated politics of marriages, handled by rimbe women, consolidated the cohesion of freemen over time. The preferred partner was always a cousin, either from the maternal or paternal side. Men could marry slave women and women from other ethnic groups, as purity of origins depended on the social qualities of the father. Molo and Musa forced the boundaries of rimbe endogamy, and sources remark upon Musa's habit of seizing the daughters of freemen. ${ }^{57}$ Even the conflict between Molo and Samba Eggue that led to Samba's death around $1880^{58}$ resulted, according to Samba's descendants, from Molo asking for Samba's daughter for Musa and Samba's adamant refusal.

Third, Molo and Musa's military initiatives allowed several jiyaabe to achieve a degree of hebtaare that would have been unthinkable even a generation earlier. Mohammadou Falai Baldeh's version states that Molo urged the rimbe to let their jiyaabe participate in the struggle. ${ }^{59}$ Military campaigns and raids began as soon as crops were ready, and continued throughout the dry season. Fighting enhanced the social cohesion of combatants as much as their emancipation: after having taken their share, Molo and Musa (who acted as his father's righthand man) redistributed the booty in grains, cattle and women to their fol-

54 Interviews with Djidere Baldé, locality of Sare Yoro Tening, Department of Velingara, Kolda Region 20 Feb. 2014, 11 Aug. 2014, 20 Aug. 2014.

55 For instance, British sources report Musa's attempts to free his subjects enslaved by other military leaders of the time. See TNA, Kew Gardens, London, co 879/29/4, African no. 36o, West Africa: correspondence relating to territories on the River Gambia, 1888 Nov. 101890 Jan. 3, Administrator Carter, 27 Mar. 1889, Tour in the upper river, no. 75, Enclosure.

56 The most famous episode is that of Sellu Koyada Mballow. See Innes, Kaabu, and Sidibé, A Brief History, 100-101.

57 Interview with Bouly Sabally, Locality of Sare Bossejo, Department of Velingara, Kolda Region, 15 Jan. 2015 .

$5^{8}$ Interview with Saba Ndyaye Balde, Kolda, 4 Feb. 2014; Rôche, Histoire, 129.

59 Baldeh, Fuladu History. 
lowers. Men of slave origins thus had a chance to establish their autonomous hamlets without relying on rimbe's support: having a wife was difficult in those times of polygamy, more so for a jiyaado, who had to wait for his master to get one for him. A new model of freemen emerged based on the idea that the qualities of a person did not depend on ancestry but rather destiny, moral and physical strength, and to some extent sacrifice. ${ }^{60}$ As with other nineteenthcentury European and North Atlantic ideas of liberty, these possibilities were not available to all human beings but were rather restricted to adult men, the only ones entitled to the benefits and the social and political responsibilities of freedom. The novelty of Molo and Musa's message lay in the fact that each man had the right to develop his potential to advance economically, socially and politically. The freeman of their times asserted his leadership over a network of wives, children, relatives, dependents and even slaves, and fully participated in the decision-making of the local community.

\section{Power Restoration in the First Part of the Twentieth Century}

Molo and Musa's attacks to the enclosures of ndimaaku sparked innumerable conflicts. Molo was alive when rimbe military leaders challenged his authority. Together with Samba Eggue's episode, oral history reports other incidents in which both he and Musa struggled with rimbe over the concreteness of freedom. It seems that at a certain point even Fouta Jallon asked Molo to hand the leadership of Fuladu over to a dimo ${ }^{61}$ This was illustrative of the rimbe's way of thinking: having served the purpose of overthrowing Mandinka hegemony, the jiyaado should now step back. On this issue, Musa made his position clear after Molo's death in 1881. The treaty of military collaboration that he signed with the French in 1883 helped him sever the ties with Fouta Djallon, which his father had subscribed to. ${ }^{62}$ He played this strategy for the next twenty years: drawing on the external power of the Europeans and manipulating their rivalries in order to strengthen his position in Fuladu. By serving French military interests, he pushed his influence eastward and southward. Each battle produced captives, whom he either traded to the northern parts of Senegal and to Fouta Jallon or assimilated into his entourage and army. Under these circumstances of generalized warfare, even as the meaning of freedom was

\footnotetext{
6 Carpenter, Sovereignty, 37.

61 Rôche, Histoire, 129; Sow, Mutations politiques, 61-62.

62 Rôche, Histoire, 238-242.
} 
changing, so was slavery becoming more and more a temporary condition caused by war or poverty that did not stain future generations. Oral history reports Musa having made statements in this direction on several occasions. ${ }^{63}$ In 1903, his departure for British Gambia initiated another process of change, as the French took over control of Hamdallay and liberated the captives and slaves he left behind. A village de liberté was set up in Kolda, ${ }^{64}$ and the freed slaves were put to construction works: the residence, prison, and all else that was necessary to transform a settlement of a few hamlets into the base of the French administration of the Upper Casamance. By 1909, the year in which the French definitely settled in Kolda, the French Resident had established the tradition of celebrating the 14 July anniversary of the French Revolution by raising the flag and singing the Marselleise. ${ }^{65}$ His reports were written on letterhead that carried the motto "Republique Francaise. Liberté, Egalité, Fraternité."66 There was a page for taxes, another for court cases and prisoners, and one for horses (their health condition, their names and those of their grooms). ${ }^{67}$ The scanty references to slaves show that even before the 1905 decree they had begun to ask for freedom certificates: they were recent captives who either returned to their home communities or sought a place where to settle in the largely underpopulated lands of Fuladu. ${ }^{68}$ French officials only marginally delved into local ideas of slavery to observe that slaves performed all of the hard work. ${ }^{69}$ British reports of the same period cast light on the tendency of colonial officials to minimize the importance of slavery in the social life of Fuladu Fulbe: "In the first place, slaves are always adopted, their time is their own and they may acquire property or may even inherit their master's property; in fact, they are in no sense slaves, although they are not regarded as freeborn people [...]

63 Alice Bellagamba, “'The Little Things that would Praise Your Hearth ...': Enslavement and Slavery in the Narrative of Al Haji Bakoyo Suso (The Gambia)," in Alice Bellagamba, Sandra E. Greene, Martin A. Klein, eds., African Voices on Slavery and the Slave Trade (Cambridge: Cambridge University Press, 2016), 29-46.

64 Rôche, Histoire, 299; ANS 2G5 30, Sénégal, Cercle de Sedhiou, Poste d'Hamdallay, Rapports mensuels d'ensemble 1905.

65 ANS 2G5 30, Sénégal, Cercle de Sedhiou, Poste d'Hamdallay, Rapports mensuels d'ensemble 1905 .

66 ANS, 2G-9 40, Sénégal, Casamance, Administration Superior, Rapports mensuels d'ensemble 1909 .

67 ANS, 2G-9 40, Sénégal, Casamance, Administration Superior, Rapports mensuels d'ensemble 1909 .

68 ANS, 2G3-48, Sénégal, Résidence d'Hamdallay, Rapports politiques mensuels 19o3; ANs, 2G4-40, Sénégal, Résidence d'Hamdallay, Rapports politiques mensuels 1904.

69 ANS, 1G 330, Charles de La Roncière, Coutumes du Sénégal, 19o7, Coutumes peulhes. 
It is a curious fact that a Fullah will, without hesitation, when asked tell one whether is freeborn or not."70

The most significant process set in motion by colonization was not the liberation of the slaves but the reassertion of the old legacy of jiyaabe and rimbe cohabitation and hierarchical collaboration that occurred over the trend of liberation set in motion by Molo and by Musa. Literature on French West Africa provides ample evidence of how colonial officials tried to minimize the impact of abolitionary regulations on the ground. ${ }^{71}$ In the case of the Upper Casamance, there is no trace of any effort made to inform the population about the end of slavery or of the slave trade. Even more relevant for the analysis of jiyaabe and rimbe relations is the fact that by asserting their leadership over the legacies of Musa, whom they started to depict as a tyrant feared by the population beginning in the 1890 s, ${ }^{72}$ the French ended up indirectly supporting the restoration of rimbe power. One of the major written sources on the late nineteenth and early twentieth-century history of Fuladu is a report written in 1904 by the French Resident Charles de La Roncieré. ${ }^{73}$ In it, there is evidence that Molo and Musa made concessions to the economic and social power of the rimbe. For instance, Musa exempted the rimbe villages from the corvées that had become part of Fuladu social life because of the 1896 treaty with the French. The French needed porters to travel through Fuladu, and Musa became responsible for road maintenance: the rimbe villages did not participate in this effort, just as they did not join the gangs of men and women who cultivated Musa's fields of millet and groundnuts near his capital Hamdallay.

At the same time, Molo and Musa's repeated attacks on ndimaaku produced their results. In a way similar to the British report quoted above, de La Roncieré reported that the rimbe had learned to let powerful jiyaabe marry their daughters, and in order to acknowledge the children of these unions they had even started to say that ndimaaku depended on the mother, rather than on the father.

70 Tenant Stanley, Notes on the physical distribution.

71 Roberts, “The End of Slavery”; Klein, Slavery; James F. Searing, 'God Alone is King': Islam and Emancipation in Senegal: The Wolof Kingdoms of Kajoor and Bawol, 1859-1914 (London: James Currey, 2002); M. Rodet, "Escaping Slavery and Building Diasporic Communities in French Soudan and Senegal, ca. 1880-1940," The International Journal of African Historical Studies 48, no. 2 (2015): 363-386.

72 ANS, 13 G 373, 1895-1888, Casamance, Mission de Captaine Baurés, 2 Aug. 1894; Rôche, Histoire, 298-302; ANS, 13 G 377, Casamance, Dossier Moussa Moloh, Almamy; ANS, 13 G 550, Dossier confidentiel sur Mussa Molo. Rapport du résident Riembam, 11 Oct. 1902.

73 ANs, Dakar, 1G-294, Charles de La Roncière, Travail d'hivernage, Historique du Fouladou (1904). 
It was under the umbrella of the French civilizing mission that local ideas of freedom and slavery as hereditary conditions gained a renewed strength.

French officials in this period believed that Africans were inferior to French people. Nonetheless, this difference had gradients; some groups were closer, while others were more distant from the French. The French liked the Fulbe: their physical appearance — tall, lean and light-skinned — set them apart from other Senegambians and their aristocratic manners impressed French officials, even those with Republican ideals and an anti-feudal stance. ${ }^{74}$ The Fulbe they talked about were the rimbe, because they came to share the rimbe's view that the jiyaabe were not truly Fulbe, and were eternal outcasts of Fulbe society. For de La Ronciére, the fula jongo, whom another French official, Liotard, had described some years before as a combination of Mandinka and Fulbe virtues, was instead a man of all races. ${ }^{75}$ His list of Fuladu regions and influential men distinguished between chiefs of noble or slave origins. All were Musa's men, as Musa had followed Molo's line to entrust several areas of Fuladu to the control of the rimbe in exchange for heavy tributes in cattle, and to nominate men of slave origins and members of other ethnic groups to positions of responsibility. The perspective of de La Ronciére was different. In the fear that Musa would later try to return to the Upper Casamance, he distrusted men too close to him, preferring instead rimbe influential personalities, whose support he thought he could reasonably gain even if they had been loyal to Musa. There was some wisdom in this perspective. Rimbe resented the seizing of their cattle even more than that of their daughters, and some herding families had moved to the north bank of the Gambia River precisely to avoid Molo and Musa's requests of cattle in support of the army.

One particular passage of de La Ronciére opens a window on the repositioning of the rimbe vis-a-vis the jiyaabe. The French Resident remarked on Molo's slave origins and downplayed his political leadership by depicting him as the companion of two free Fulbe: "three among them, having nothing more to lose, decided to fight the oppressors. They were Coly Demo of Sabary, Samba Eggue of Dialaba, and Molo Eggue - after known as Alpha, of Soulabally. Two among them were freeborn Fulbe (fula forolo), Molo Eggue was a Fulbe born in slav-

74 Alice L. Conklin, "Colonialism and Human Rights, a Contradiction in Terms? The Case of France and West Africa, 1895-1914," The American Historical Review 103, no. 2 (1998): 419442. On the representation of Fulbe by colonial officials see, for instance: P. Brasseur and G. Brasseur, "Le peul imaginaire," Revue française d'Histoire d'Outre-mer 65, no. 241 (1978): 535-542; Breedveld and de Bruijn, "L' image des Fulbe"; A. Pondopoulo, "L'image des Peul dans l' œuvre du General Faidherbe," History in Africa 23 (1996): 279-299. 
ery (Foula dion), but his reputation as elephant hunter made him a precious attendant in the eyes of the others." ${ }^{76}$

Representatives of influential rimbe families subscribed to this view, which has today become the Kolda version of Fuladu history. Mohammadou Falai Balde's version, as well as oral history from The Gambia, expose instead the tensions between Molo, Musa and the rimbe. By putting Molo behind, and not in front, de La Ronciére was giving voice to a cry that has long resonated throughout the Kolda region at election time: "jiyaado lamatako,"77 or "the jiyaado cannot lead." Politicians have used it strategically to pit their jiyaabe constituencies against rimbe candidates. In de La Ronciére's time, the same cry served to undermine the political, social and economic upgrading that some of the jiyaabe enjoyed under Molo and Musa. It took time but chiefs of jiyaabe origins either lost their position or were unable to establish a line of descendants that retained the powers given to them by Musa. In addition, the end of warfare eliminated one of their main sources of revenue. It is true that the jiyaabe were more competent farmers than the rimbe, but as made clear by the Roland Portères' Mission of the 1950s on the problems of Senegalese agriculture, the cash-crop economy of groundnuts created "a new class of serfs, or perhaps it would be better to say 'slaves." "78 Portères was talking about the groundnut basin, the region north of the Gambia River where commercial agriculture expanded more significantly thanks to the collaboration between commercial companies, the colonial state and the Muslim religious elite. The social structure of the Upper Casamance was different: religious leaders were few and their influence confined to their agricultural settlements. Influential men there instead included traders, representatives of European commercial companies, rimbe canton chiefs and cattle-owners. Thanks to the labor of jiyaabe - which they obtained in exchange for cattle, milk and millet during the difficult months of the rainy seasons, when granaries were empty and peasants toiled in the fields - the latter had caught up with commercial groundnut cultivation, and their herds benefitted from the vaccination campaigns of the colonial state. ${ }^{79}$ With the exception of the canton of Kamako, all of the chiefs

76 ANS, Dakar, 1G-294, Charles de La Roncière, Travail d'hivernage, Historique du Fouladou (1904).

77 N'gaïdé, L'esclave, $87 \mathrm{fn}$. 111.

78 Roland Portèrs, Amenagement de l'economie agricole et rurale au Sénégal: rapport de la Mission Roland Portères (Dakar: Gouvernement General de TAOF, Territoire du Senegal, Mar.-Apr. 1952), 105.

79 Pellissier, Les paysans, 526. Dominique Darbon, L'administration et le paysan en Casamance: essai d'anthropologie Administrative (Paris: Editions A. Pedone, 1988). 
were rimbe by the 1950s. Through their kin, kindred and close associates they controlled the lower apparatus of the colonial state and economy: the "sons" of chiefs acted as tax collectors, rural constables, census officials, and served in the ranks of the Sociétés Indigènes de Prévoyance (SIP), the early French West African version of cooperatives. ${ }^{80}$ The jiyaabe, who belonged to the chieftaincy houses and their social networks, enjoyed some of their masters' privileges; the others stayed at the bottom of the Upper Casamance social ladder-a hungry workforce of peasants that experienced all the coercion of indigénat, i.e. the special penal code for French colonial subjects. ${ }^{81}$

Oral history uses three terms to explain how people turned into jiyaabe before colonization: through capture (nanngugol), purchase (soodugol), and asking for refuge (moolagol). ${ }^{82}$ Only the latter remained in use after abolition as part of the experiences of the numerous immigrants from Portuguese and French Guinea, many of whom were of slave ancestry, who sought hebtaare in the Upper Casamance. ${ }^{83}$ The other term, which applied to post-abolition jiyaabe, is terima, a Mandinka word typical only of the Fulfulde spoken in former Fuladu territories. ${ }^{84}$ It means "friendship" between people and families linked neither by capture nor purchase yet positioned as jiyaabe and rimbe. It was easy to slip again into subjection by establishing relations of dependence with powerful rimbe or with the canton chiefs, for whose protection individuals and communities negotiated, either forced by circumstances or voluntarily. The peasant with relations could try to pay his children off from military conscription or forced labor: he could have a role in SIP, and hope to hide some of his cattle from the sharp eyes of the tax collector. The man without relations, instead, was an easy prey for the coercive system put in place by the French administration after having freed the indigenous population from the arbitrary rule of Musa and the chains of slavery.

8o Catherine Boone, Merchant Capital and the Roots of State Power in Senegal: 1930-1985 (Cambridge: Cambridge University Press, 2006), 41.

81 G. Mann, "What was the Indigenat? The 'Empire of Law' in French West Africa," The Journal of African History 50, no. 3 (2009): 334; see also Jean Suret Canale, French Colonialism in Tropical Africa (London: Hurst, 1971), 331-336.

82 N'gä̈dé, L'esclave, 91. See also Bowman, Ominous Transition; and in a comparative perspective Sehou, L'esclavage, 299-308.

83 ANS 2G 36-79, Sénégal, Kolda, Rapport politique annuel 1936; N'gaïdé, L'esclave, 156.

84 David P. Gamble and Mary Umah Baldeh, Gambian Fula-English Dictionary (Firdu Dialect), Gambian Studies No. 12, 1981 (accessed at: http://www.smcm.edu/gambia/wp-content/ uploads/sites/31/2015/03/gamble-12.pdf on 23 Dec. 2016). 


\section{Senegalese Independence and the Real End of Slavery}

In 1948, Leopold Sedar Senghor and his close political associate Mamadou Dia left the Section Française de l'Internationale Ouvrière (SFIO) to establish the Bloc Democratique Senegalais (BDS). ${ }^{85}$ One year later, Senghor visited Kolda. Although he received a limited response from a rural population that colonial officials described as largely apathetic, this was the real beginning of politics in the Upper Casamance. ${ }^{86}$

Until this moment, discussions in metropolitan France and its overseas dominion that touched upon the two fundamental institutions of French domination, forced labor and the indigénat, had hardly reached the region. The Constituent Assembly of the Fourth Republic abolished forced labor in 1946. The indigénat broke down because of reforms that had been enacted for at least two decades, the last being the 1946 Lamine Guéye Law, which granted citizenship to all inhabitants of French overseas colonies. This was not yet the era of universal franchise, which arrived with the Loi Cadre of $1956 .^{87}$ Senegal's voting rolls, nonetheless, increased "from 45,000 to 130,000." 88 Rural notables, employees of commercial companies, soldiers, veterans, and an array of people who "shared the attribute of having written evidence of who they were" entered the political stage. ${ }^{89}$

The BDS immediately won the peasantry. ${ }^{90}$ In their effort to capitalize on the patronage networks of the colonial period, Senghor and Dia "bargained with and made promises to rural notables and influentials." ${ }^{\text {91 }}$ In the groundnut basin, they sought the support of Muslim religious leaders. ${ }^{92}$ In the Upper

85 Hesseling, Histoire Politique, 160; S. Kras, “Senghor's Rise to Power 1948-1951: Early Roots of French Sub-Saharan Decolonisation," Itinerario 23, no. 1 (1999): 91-113; K. Heitz, "Décolonisation et construction nationale au Sénégal," Relations internationales 1, no. 133 (2008): $41-52$.

86 ANS, 2G50-100, Sénégal, Subdivision de Kolda, Rapports politiques trimestriels, 1950.

87 Hesseling, Histoire Politique, 161.

88 Frederick Cooper, Africa since 1940: The Past of the Present (Cambridge: Cambridge University Press, 2002), 45 .

89 Frederick Cooper, Citizenship, 137-138.

go É. Smith, "Senghor voulait qu' on soit tous des Senghor," Vingtième Siècle. Revue d'histoire 2 (2013): 87-100.

91 Catherine Boone, Merchant Capital and the Roots of State Power in Senegal: 1930-1985 (Cambridge: Cambridge University Press, 2006), 82.

92 For instance Edward Schumacher, Politics, Bureaucracy and Rural Development in Senegal (Berkeley: University of California Press, 1975); Donald Cruise O'Brien, Saints and Politicians: Essays in the Organisation of a Senegalese Peasant Society (Cambridge: Cambridge 
Casamance, they approached traders, based in Kolda and in Velingara (the administrative and commercial center near the border with The Gambia), canton chiefs, and educated young men who served as teachers or low rank civil servants. Some of the latter adhered to the Mouvement de Force Democratique de la Casamance (MFDC), a group of Casamance intellectuals founded in 1947 to mobilize against the marginalization of the region in national politics. MDFC lamented that the SFIo had never truly consulted the regional electoral base before choosing its candidates for the Casamance..$^{93}$ The support of the movement was crucial to the BDS victory at the $195^{2}$ elections of the Territorial Assembly. The secretary of the movement was Yoro Kande, the son a migrant from Portuguese Guinea who had settled in a small jiyaabe village founded at the beginning of the twentieth century by people from various places, including Musa's residence in Hamdallay. After having attended the rural school built by the canton chief, Yoro continued his studies in the French Sudan. After World War II, he started teaching in Bignona. While in the Casamance, he entered the MFDC. In 1951, he asked to be posted to Kolda. There, his political career began.

The BDS candidate for Kolda was Abdoulay Diop (known as Michael Diop), ${ }^{94}$ who traded in cattle and groundnuts. Because of cattle, he knew the rimbe herders of the region. Because of his trade in groundnuts, he became familiar with the challenges of the average peasant. Food distribution or debt cancellation could win the vote of any farmer. Diop was also friendly to the Diao, one of the influential rimbe families on the eastern side of the Kolda region. Some say that Yoro became the candidate for Velingare because he was a relevant figure within the MFDC. However, others underlined that the canton chief himself recommended him because of his education. At the time nobody really understood how radical he was. The Velingara side of the Upper Casamance was one of the areas where the dependence of the jiyaabe on the rimbe was strongest. Difficult to access, it was a commercial frontier for Gambian traders, an underpopulated territory suitable to groundnut cultivation and cattle herding. Rimbe villages were economically strong but few in number. The jiyaabe largely outnumbered them: it was only a matter of putting history in motion again. His jiyaabe ancestry linked Yoro to the majority of the population whose needs he

University Press 1977); Linda J. Beck, Brokering Democracy in Africa: The Rise of Clientelist Democracy in Senegal (New York: Palgrave Macmillan, 2008).

93 Rôche, Le Sénégal, 75; Seck, Sénégal, 29; Interview with Mountaga Diao, 3 Jan. 2014 and 4 Jan. 2014.

94 ANS 1G/oo 169, Dial Diop, Monographie de Department de Kolda; Sow, Mutations politiques, 212-213. 
felt as his own. Though educated - and thus accustomed to a different style of life-he slept in villages, drank the villagers' water and shared their basic food. There was millet but not the abundance of milk typical of rimbe communities. People relied on groundnuts, leaves, wild fruits and manioc to make sauce. When Yoro started his political mobilization for the $195^{2}$ elections, the people did not even know that forced labor had been abolished almost eight years before. There was no radio in the rural areas and nobody could read a newspaper. The news he carried was therefore revolutionary. "Mi saltima"-I refuse-became the slogan of his militants who stopped working at the request of colonial officials and canton chiefs. As a member of the Territorial Assembly, Yoro inspected colonial construction sites to see how workers were treated. He advised people on how to develop their families, he sought jobs for his militants, and he urged them to educate their children. His political campaigns struck at the core of rural inequalities in order to destabilize rimbe political and economic leadership: the jiyaabe who continued working for the rimbe should do so only if remunerated. For elders who were young in those days, this was the real end of slavery, not 1905. In the recollections of Bassy Diao, who lived through that historical period, independence made the difference: "Before, I would have given all your daughters in marriage but you as well could do what you liked with my family without complaints from anybody. My rimbe are the Mballo of Kulinto. Madia Mballo was the owner of my parents, he did as he liked with us." 95

Though many elders of Bassy's generation admired Senghor more than any other president of Senegal, he did remain a distant personality: he did not speak Fulfulde, and people listened to his discourses through interpreters. Yoro, instead, mastered the language. Fulfulde is rich in metaphors that stem from the long association of the Fulbe with the bush. For instance, the rimbe are associated with the small red monkeys, and the jiyaabe with the bigger black ones. ${ }^{96}$ Yoro used ordinary daily expressions, such as the simple morning greeting honopindom (are you well awake?) to instill in the people a sense of growing awareness or even enlightenment, which in Fulfulde is pinnal. ${ }^{97}$ The act of retrieving one's independence-hettugol hore mun - passed through a change of mentality: the jiyaabe had to look directly in the eyes of the rimbe

95 Interview with Bassy Diao, locality of Koulandiala, Department of Velingara, Kolda Region, 17 Feb. 2017. One of the people in the room was a dimo; when Bassy says "you," he refers to this man.

96 Interview with Mamadou Abdoul Diallo (Boboyel), Kolda 7 Feb. 2014.

97 Interview with Alieu Baldé, Kolda 13 Feb. 2014. 
and show them that they were brave, strong, and that they were the founders of Fuladu. Did they ignore that Molo had the same origins as them?

Elizabeth Schmidt has observed how this generation of African politicians revived local traditions that their French education had taught them to despise. ${ }^{98}$ For Yoro, there was an additional element: by definition people without history, the jiyaabe were the people who had made Fuladu. In 1957, his militants gained over thirty-four seats in the General Assembly of the Société Mutuelle Production Rurale (SMPR) for the Kolda Subdivision, one of the manifestations of the SIP in the 1950s. The victory was a local refraction of the radical reforms that Mamadou Dia, at the leadership of Senegalese government after the Loi Cadre of 1956, was trying to promote in the agricultural sector. ${ }^{99}$ The SMPR were to become real cooperatives in order to empower the peasantry against the interests and pressures of foreign commercial companies and rural patrons. The key to such developments was the method of rural animation, which entrusted local intellectuals like Yoro with the responsibility of making people aware of the freedoms and rights attached to their new status as citizens. ${ }^{100}$ This "populist revolution from below" troubled the rural notables and patrons who supported Senghor and Dia.

Dia's efforts to boost rural change increased after the achievement of independence in 1960, and as a reaction, the Muslim religious leaders of the groundnut basin began to plea for his removal. ${ }^{101}$ Kolda was a multi-ethnic town where

98 Elizabeth Schmidt, “Top Down or Bottom Up? Nationalist Mobilization Reconsidered, with Special Reference to Guinea (French West Africa)," The American Historical Review 110, no. 4 (2005): 987 .

99 Mamadou Dia, Réflexions sur l'économie de l'Afrique noire (Paris: Éditions Africaines, 1952); Mamadou Dia, Contribution à l'étude du mouvement coopératif en Afrique noire (Paris: Présence Africaine, 1957); Mamadou Dia, L'Économie africaine: Études et problèmes nouveaux (Paris: PUF, 1957). See also Adama Baytir Diop, Le Sénégal à l'heure de l'indépendance: le projet politique de Mamadou Dia (1957-1962) (Paris: Editions L'Harmattan, 2008), and Colin, Sénégal, to capture the overall intellectual climate of the period.

100 A. Diakhate, "L'animation rurale pour l'émancipation des populations: des perspectives pour le développement du Sénégal," Journal of Sociocultural Development and Practices 8 (2015): 55-62 (accessed at http://www.atps.uqam.ca/numero/n8/pdf/ATPS_Diakhate _2015.pdf, 4 Jan. 2017). See also Sheldon Gellar, Robert B. Charlick and Yvonne Jones, Animation Rurale and Rural Development: The Experience of Senegal (Ithaca, N.Y.: Cornell University, 1980), 72-73.

101 Boone, Merchant Capital, 93-94; see also Schumacher, Politics, 66-67; I.L. Markovitz, "Traditional Social Structure, the Islamic Brotherhoods, and Political Development in Senegal," Journal of Modern African Studies 8, no. 1 (Apr. 1970): 73-96; Gabriel Gagnon, "Cooperatives, Participation, and Development:Three Failures," in June Nash, Jorge Dandler, and 
each group sought social and economic promotion through participation in national politics. Peasant empowerment was not a priority for the city dwellers. Their dissatisfaction with Yoro's populism was matched by that of the rimbe and of the trading elite whom jiyaabe accused Yoro of racial politics. In the words of one of the participants in the political battles of those days, "he helped only his people." 102 In 1962, Senghor had Mamadou Dia arrested after a confrontation between their respective supporters. Dia was Fulbe, and his downfall affected Fulbe politicians like Yoro as well as trade unionists, leftist intellectuals and leaders. All of them were set aside by the party and in the majority of cases posted to positions in the civil service in other parts of the country. ${ }^{103}$ For the jiyaabe and the rimbe of the Kolda region, it was the beginning of another historical phase. Relations of collaboration continued, but they were remunerated. All free citizens of the Republic of Senegal, they stood together at the bottom of a highly centralized political structure, which in the day-to-day reality of rural administration did not truly disown its colonial legacies. ${ }^{104}$

\section{Conclusion}

Crawford Young's review of African ideas of freedom underlines the difficulty of generalizing across the richness of languages, cultures and social organizations. Indigenous itineraries are as relevant as exogenous notions that have influenced the African intellectual universe thanks to "colonial occupation, Western education and Christian missions." 105 The case of the Kolda region is exemplary in this respect. Molo and Musa reframed the relations between freedom and slavery within the context of a turbulent period of economic, political and

Nicholas S. Hopkins, eds., Popular Participation in Social Change: Cooperatives, Collectives, and Nationalized Industry (The Hague: De Gruyter Mouton, 1976), 365-368.

102 Interview with Hogo Mballo, Kolda, 5 Feb. 2014; Interview with Mamadou Abdoul Diallo (Boboyel), Kolda 7 Feb. 2014.

103 Boone, Merchant Capital, 94.

104 D.B. O'Brien, "Co-operators and Bureaucrats: Class Formation in a Senegalese Peasant Society," Africa 41, no. 4 (1971): 263-278; M. Diouf, "L'échec du modèle démocratique du Sénégal, 1981-1993," Africa Spectrum (1994): 47-64. Donal Brian Cruise O’Brien, Momar Coumba Diop, and Mamadou Diouf, La construction de l'Etat au Sénégal (Paris: Karthala, 2002).

105 Crawford Young, "Itineraries of Ideas of Freedom in Africa: Precolonial to Postcolonial," in Robert Taylor, ed., The Idea of Freedom in Asia and Africa (Stanford: Stanford University Press, 2002), 28-32. 
social innovations. The outcomes were controversial. On the one hand, they were late actors of the long age of enslavement: in their military campaigns, they captured hundreds of men, women, and children, trafficked in slaves and profited from slave labor. At the same time, they fully participated in the age of emancipation. They were not abolitionists but rather men who tried to conquer freedom according to the standards of their times. Under the cover of colonial rule, the rimbe reestablished their social privileges. For sure, colonization provided opportunities of emancipation to men of the likes of Yoro Kande, which researchers focused on the end of slavery in Africa have often emphasized. But it also meant also the daily oppression of peasants, and most importantly the stiffening of indigenous social hierarchies under the overarching umbrella of colonial ones.

Elizabeth Schmidt has argued that the struggles for citizenship of the 1950s were more than top-down politics, as battles against the power structures of colonialism had already unfolded on the ground. The legacies of slavery played a role in the decolonization of British Gambia and Sierra Leone, and in the northern regions of Cameroon, which shared with the Upper Casamance the fact of being predominantly Fulbe areas, they brought into the national struggles the diverging aspirations of former masters and slaves. The former looked forward to restoring the practices that colonial abolition had swept away; the latter sought further emancipation. ${ }^{106}$ Also in Fouta Djallon, which colonization had turned into one of the provinces of French Guinea, slavery played its part in regional politics. Here, the pre-colonial elite of freemen continued to dominate politically and freed slaves and people of slave descent amounted to one-quarter of the population. ${ }^{107}$ The figures of the Upper Casamance, as mentioned in the introduction, were even higher. Unlike in French Guinea, however, the BDS of Senghor and Dia never meant to destabilize regional hierarchies, and eventually Senghor and Dia parted precisely because of Dia's radical perspective on the economic and political empowerment of the peasants. While Guinea abolished chieftaincy immediately after independence in 1958, Senegal really managed a slow transition from a hereditary chiefship to professionally trained civil servants by transforming the canton chiefs into chefs

106 C. Whyte, “'Freedom But Nothing Else:' The Legacies of Slavery and Abolition in PostSlavery Sierra Leone, 1928-1956," The International Journal of African Historical Studies 48, no. 2 (2015): 231-250; Alice Bellagamba, "After Abolition: Metaphors of Slavery in the Political History of the Gambia," in Benedetta Rossi, ed., Reconfiguring Slavery: West African Trajectories (Liverpool: Liverpool University Press, 2009), 63-84; Sehou, L'esclavage.

107 Elizabeth Schmidt, Cold War and Decolonization in Guinea, 1946-1958 (Athens: Ohio University Press, 2007). 
d'arrondissment. For the Kolda region, two of these chiefs hailed from prestigious rimbe families that by the time of decolonization had clearly understood the importance of French-style education. ${ }^{108}$ The origins of Yoro and the climate of populist reforms that developed under the leadership of Dia helped the resurgence of Molo's emancipatory spirit. On the eastern side of the Kolda region there are today many jiyaabe villages, which were founded at the time of independence by jiyaabe who, thanks to economic benefits provided by state intervention in the agricultural sector, finally decided to achieve jeyal-hoore mun in the full sense of the expression.

The lesson learned from this historical reconstruction moves beyond the entanglement of the historical grassroots of freedom with slavery and its legacies. It discloses unfulfilled emancipatory projects, and carries along the echo of people's aspirations for the world-to-be and of their attempts to shape themselves under changing and unpredictable circumstances. The underlying message is simple. The problem is not to understand how African societies reacted to the implanting of Western ideas of freedom and got rid of slavery, but rather of capturing the processes through which, in their own ways and following their own agenda, they have been active participants in discussions about freedom and slavery. This local narrative pulses at the rhythm of world history.

108 F. Zuccarelli, "De la chefferie traditionnelle au canton: évolution du canton colonial au Sénégal, 1855-1960," Cahiers d'études Africaines 12, no. 50 (1973): 213-238. 